Check for updates

Cite this: RSC Adv., 2017, 7, 39594

\title{
Adsorptive removal of aqueous bezafibrate by magnetic ferrite modified carbon nanotubes $\uparrow$
}

\author{
Donghai Wu, (D) a Jingjing Yao, (D) ab Guanghua Lu, ${ }^{\text {*ab }}$ Fuli Liu, $^{\text {a }}$ Chao Zhou, ${ }^{\text {a Pei Zhang }}{ }^{\mathrm{c}}$ \\ and Matthew Nkoom ${ }^{a}$
}

In this work, magnetic ferrite modified carbon nanotubes ( $\mathrm{MFe}_{2} \mathrm{O}_{4} / \mathrm{CNTS}, \mathrm{M}$ : Mn or $\mathrm{Co}$ ) were synthesized and employed as adsorbents to remove emerging pollutant bezafibrate (BZF) from aqueous solution. The structural and surface properties of the prepared adsorbents were characterized, and the performances of the $\mathrm{MFe}_{2} \mathrm{O}_{4} / \mathrm{CNTS}$ were systematically investigated from adsorption kinetics and mechanistic points of view. Results showed that the fabricated $\mathrm{MFe}_{2} \mathrm{O}_{4} / \mathrm{CNTS}$ could integrate the advantages of CNTs and ferrite, thereby exhibiting an excellent adsorption performance and recyclability. The $\mathrm{MnFe}_{2} \mathrm{O}_{4} / \mathrm{CNTS}$ were more effective than $\mathrm{CoFe}_{2} \mathrm{O}_{4} / \mathrm{CNTS}$ for BZF adsorption. When the initial concentration of BZF was varied from 5 to $40 \mathrm{mg} \mathrm{L}^{-1}$, the maximum adsorption capacity of $\mathrm{MnFe}_{2} \mathrm{O}_{4} / C N T s$ and $\mathrm{CoFe}_{2} \mathrm{O}_{4} / \mathrm{CNTs}$ increased from 14.8 to $33.4 \mathrm{mg} \mathrm{g}^{-1}$ and 8.1 to $27.8 \mathrm{mg} \mathrm{g}^{-1}$, respectively. Moreover, the Langmuir isotherm model and pseudo-second-order equation could elaborate well the adsorption of BZF on $\mathrm{MFe}_{2} \mathrm{O}_{4} / \mathrm{CNTS}$. The thermodynamic analysis further revealed that the adsorptions were spontaneous processes. Based on measurements of surface and pore diffusion and the results of adsorption reactions, possible mechanisms were proposed to explain the adsorption process. This research indicates that the $\mathrm{MFe}_{2} \mathrm{O}_{4} / \mathrm{CNTS}$ are potentially applicable for the removal of BZF from aqueous solution.

Received 30th June 2017

Accepted 6th August 2017

DOI: 10.1039/c7ra07260k

rsc.li/rsc-advances
$\left(\mathrm{HO}^{*}\right)$ and have been recommended as efficient technologies for water treatment. ${ }^{\mathbf{1 1}, \mathbf{1 2}}$ However, chemical reagents storage and formation of potentially toxic byproducts may limit their practical application. ${ }^{13}$ Adsorption is an alternative PPCPs removal technology that has a high efficiency and nearly no byproduct generation. ${ }^{\mathbf{1 4}}$ This method has been wildly applied in wastewater and drinking water purification. ${ }^{15}$ Selection of effective and recyclable adsorbent is critical for the adsorptive treatment.

In the last decade, many adsorbents have been investigated for PPCPs removal from aqueous solution, including porous carbon materials, ${ }^{16}$ metal-organic frameworks (MOFs), ${ }^{17}$ zeolite,${ }^{18}$ molecular sieve, ${ }^{19}$ etc. However, the application of the adsorbents is usually limited by high cost, difficulty in separation and regeneration. Recently, researchers are focused on the adsorbents that have high efficiency, safety and regeneration capacity. ${ }^{\mathbf{1 4}}$ Carbon nanomaterials, such as graphene-based nanomaterials and carbon nanotubes (CNTs), have been found to be efficient and economic adsorbents for the adsorptive removal of aqueous antibiotics. ${ }^{16}$ Carboxyl modification could enhance CNTs adsorptive removal of the pharmaceutical drug from aqueous solution. ${ }^{20}$ Nevertheless, poor separability also restricts their practical application, and the release of CNTs during water treatment could induce secondly pollution. ${ }^{21,22}$ Using magnetic nanomaterials modified CNTs maybe a possible way to overcome this defect. Among the various magnetic materials, ferrites exhibit high efficiency and are environmentally friendly. ${ }^{23,24}$ Some ferrites, such as $\mathrm{MnFe}_{2} \mathrm{O}_{4}$
${ }^{a}$ Key Laboratory of Integrated Regulation and Resource Development on Shallow Lakes of Ministry of Education, College of Environment, Hohai University, Nanjing 210098, China.E-mail: ghlu@hhu.edu.cn

${ }^{b}$ College of Hydraulic and Civil Engineering, XiZang Agricultural and Animal Husbandry College, Linzhi, 860000, China

${ }^{c}$ Henan Province Hydrology and Water Resources Bureau, Zhengzhou, 450004, China

$\dagger$ Electronic supplementary information (ESI) available. See DOI: 10.1039/c7ra07260k 
and $\mathrm{CoFe}_{2} \mathrm{O}_{4}$, are excellent adsorbents, and their magnetic properties ensure that they can be magnetically separated. ${ }^{25}$ Furthermore, synergistic adsorptive removal of heavy metals from aqueous solution has been reported for combined application of ferrite and carbon materials. ${ }^{26}$ Considering the excellent performance and low cost, ferrites may be applicable to modify CNTs for adsorptive water treatment. However, the effects of ferrite on the performance of CNTs are largely unknown, and few systematic studies have examined the use of ferrite/CNTs for the adsorptive treatment of BZF containing wastewater.

This work mainly focused on four aspects: (I) preparation and characterization of ferrite modified CNTs adsorbents $\left(\mathrm{MFe}_{2} \mathrm{O}_{4} / \mathrm{CNTs}, \mathrm{M}\right.$ : Mn or Co); (II) efficiency of BZF removal by $\mathrm{MFe}_{2} \mathrm{O}_{4} / \mathrm{CNTs}$ adsorption; (III) examination of adsorption kinetics, isotherms, and thermodynamics; (IV) investigation of the possible adsorption mechanism.

\section{Materials and methods}

\subsection{Materials and reagents}

Multi-walled CNTs (purity $>98 \%, 30-50 \mathrm{~nm}$ of outer diameter) were bought from Chengdu Organic Chemistry Co., Ltd, Chinese Academy of Sciences; BZF was purchased from Sigma Aldrich, and its physicochemical properties and structure are provided in Table S1. $\dagger$ Methanol with HPLC grade was supplied by Merck \& Co. The other chemicals (e.g., $\mathrm{Fe}\left(\mathrm{NO}_{3}\right)_{3} \cdot 9 \mathrm{H}_{2} \mathrm{O}$, $\mathrm{CoCl}_{2} \cdot 6 \mathrm{H}_{2} \mathrm{O}, \mathrm{MnCl}_{2} \cdot 4 \mathrm{H}_{2} \mathrm{O}, \mathrm{HNO}_{3}$, and polyethylene glycol) were analytical grade without any further purification. Ultrapure water (18.25 M $\Omega \mathrm{cm}$, Milli-Q, Millipore, Billerica, MA, USA) was used throughout the experimental process.

\subsection{Synthesis of $\mathrm{MFe}_{2} \mathrm{O}_{4} / \mathrm{CNTS}$}

CNTs were pretreated by $65 \mathrm{wt} \% \mathrm{HNO}_{3}$ solution to remove surface impurities and reduce agglomeration according to the procedure described elsewhere, ${ }^{27}$ except that the reaction was carried out in a Teflon-lined stainless-steel autoclave.

Since $\mathrm{MnFe}_{2} \mathrm{O}_{4}$ and $\mathrm{CoFe}_{2} \mathrm{O}_{4}$ have been proven to have good adsorbing properties for water purification, ${ }^{28}$ they were employed to modify CNTs, respectively. The $\mathrm{MFe}_{2} \mathrm{O}_{4} / \mathrm{CNTs}$ (M: $\mathrm{Mn}$ or $\mathrm{Co}$ ) were synthesized using a hydrothermal method under magnetic stirring. Briefly, $5.0 \mathrm{mmol} \mathrm{Fe}\left(\mathrm{NO}_{3}\right)_{3}$ and

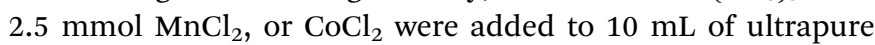
water under magnetic stirring. After the mixture was completely dissolved, $20 \mathrm{~mL}$ of polyethylene glycol was added to the solution and stirring continued for $30 \mathrm{~min}$. Then approximately $0.6 \mathrm{~g}$ of the acid-treated CNTs were impregnated into the solution with continuous magnetic stirring for $30 \mathrm{~min}$. After that, 2 mol L ${ }^{-1} \mathrm{NaOH}$ solution was added dropwise to the mixture with stirring at $400 \mathrm{rpm}$ for $30 \mathrm{~min}$ until the $\mathrm{pH}$ value reached 11. Thereafter, the suspension was transferred to a $100 \mathrm{~mL}$ Teflon-lined stainless-steel autoclave, sealed and hydrothermally treated at $180{ }^{\circ} \mathrm{C}$ for $24 \mathrm{~h}$. After cooling to room temperature, the material was collected by a magnet and washed repeatedly with ethanol and ultrapure water. It was finally dried in an oven at $60{ }^{\circ} \mathrm{C}$ for $12 \mathrm{~h}$. The products were denoted as
$\mathrm{MFe}_{2} \mathrm{O}_{4} / \mathrm{CNTs}$ (M: $\mathrm{Mn}$ or Co). $\mathrm{MFe}_{2} \mathrm{O}_{4}$ were prepared by the same method, except the absence of CNTs.

\subsection{Experimental set-up and conditions}

A stock solution $\left(1.0 \mathrm{~g} \mathrm{~L}^{-1}\right)$ of the BZF was first prepared in phosphate buffer solution ( $\mathrm{pH}$ 7.2) and stored in the dark at $4{ }^{\circ} \mathrm{C}$. Experimental solution was prepared by diluting the stock solution in ultrapure water.

In a typical adsorption test, $0.02 \mathrm{~g}$ of the adsorbent was mixed with $100 \mathrm{~mL}$ of the BZF solution under stirring at $25^{\circ} \mathrm{C}$. After a specified time, the sample was harvested, and filtered through a $0.22 \mu \mathrm{m}$ membrane to separate the adsorbents and solution. Then the residual BZF concentration in the separated solution was determined. The amount of adsorbed BZF is given by the following equation.

$$
q_{\mathrm{e}}=\frac{\left(C_{0}-C_{\mathrm{e}}\right) \times V}{m}
$$

where $q_{\mathrm{e}}$ is the equilibrium adsorption capacity, $\mathrm{mg} \mathrm{g}^{-1} ; C_{0}$ is the initial concentration of $\mathrm{BZF}, \mathrm{mg} \mathrm{L}^{-1} ; C_{\mathrm{e}}$ is the final or equilibrium BZF concentration, $\mathrm{mg} \mathrm{L}^{-1} ; V$ is the volume of solution, $\mathrm{L} ; m$ is the mass of adsorbent, $\mathrm{g}$.

To evaluate the reusability of the adsorbents, $0.02 \mathrm{~g}$ of $\mathrm{MFe}_{2} \mathrm{O}_{4} / \mathrm{CNTs}$ were first put in contact with $100 \mathrm{~mL}$ of $20 \mathrm{mg} \mathrm{L}^{-1}$ $\mathrm{BZF}$ for $24 \mathrm{~h}$. After adsorption, the adsorbents were separated by a magnet, and then dried at $40{ }^{\circ} \mathrm{C}$ for $24 \mathrm{~h}$. Desorption processes were conducted by mixing $0.01 \mathrm{~g}$ of the above mentioned dried adsorbents with $60 \mathrm{~mL}$ of methanol for $30 \mathrm{~min}$. Finally, the concentration of BZF in the methanol after desorption was measured. The desorption efficiency was calculated as:

$$
\text { Desorption ratio }(\%)=\frac{\text { amount of desorbed } \mathrm{BZF}}{\text { amount of adsorbed } \mathrm{BZF}} \times 100
$$

\subsection{Analytical methods}

The X-ray diffraction (XRD, Dmax-RB, Rigaku Corporation, Tokyo, Japan) equipped with a copper anode generating $\mathrm{Cu} \mathrm{K \alpha}$ radiation was used to investigate the crystal structure of $\mathrm{MFe}_{2} \mathrm{O}_{4} / \mathrm{CNTs}$ samples with a scanning range of $20-80^{\circ}$, scanning step of $0.02^{\circ}$, and stepping rate of $8^{\circ} \mathrm{min}^{-1}$. The morphologies were characterized by using a transmission electron microscope (TEM, JEM-200CX, JEOL Corporation, Tokyo, Japan) operated at $200 \mathrm{kV}$. Fourier Transform Infrared Spectroscopy (FT-IR) was recorded on FT-IR Nicolet iS10 (Thermo Fisher Scientific, USA) from 400 to $4000 \mathrm{~cm}^{-1}$. The constituents of $\mathrm{MFe}_{2} \mathrm{O}_{4} / \mathrm{CNTs}$ and the chemical analysis of the surface elements were determined by X-ray photoelectron spectroscopy (XPS, PHI 5000, ULVAC-PHI, Japan). Measurements of Brunauer-Emmett-Teller (BET) surface area and pore size distribution were performed using $\mathrm{N}_{2}$ adsorption/ desorption isotherms on a BelSorp-Mini (Bayer Corporation, Tokyo, Japan). The thermal stability and purity were analyzed by thermogravimetric-differential scanning calorimetry (TG-DSC, STA 409 PC/PG, Germany). Vibrating sample magnetometer (VSM, Lakeshore 7407, USA) was used to measure the magnetic 
prosperities of the materials. The point of zero charge measurements and Boehm titration were performed according to the procedures described in elsewhere. ${ }^{29}$ High-performance liquid chromatographic (HPLC, Waters Alliance e2998, USA) method was established for the determination of BZF, and samples were performed on SunFire C18 of phosphate buffer (0.01 $\mathrm{mol} \mathrm{L}^{-1}$ at $\left.\mathrm{pH} 3.5\right)$-methanol-acetonitrile (40: $15: 45, \mathrm{v} / \mathrm{v} / \mathrm{v}$ ) as mobile phase, at a flow rate of $1 \mathrm{~mL} \mathrm{~min}^{-1}$. The $\mathrm{pH}$ value and temperature were determined by a Thermo Orion 868 meter (USA).

\section{Results and discussion}

\subsection{Characterization of $\mathrm{MFe}_{2} \mathrm{O}_{4} / \mathrm{CNTS}$}

Fig. 1 shows the XRD patterns of acid-treated CNTs, $\mathrm{MFe}_{2} \mathrm{O}_{4}$ and $\mathrm{MFe}_{2} \mathrm{O}_{4} / \mathrm{CNTs}$. There were seven characteristic diffraction peaks in $\mathrm{MnFe}_{2} \mathrm{O}_{4} / \mathrm{CNTs}$ at $2 \theta=29.71^{\circ}, 34.98^{\circ}, 36.65^{\circ}, 42.53^{\circ}, 52.74^{\circ}$, $56.20^{\circ}$ and $61.66^{\circ}$, which corresponded to the (220), (311), (222), (400), (422), (511) and (440) facets of the face-centered cubic spinel structures of $\mathrm{MnFe}_{2} \mathrm{O}_{4}$ (JCPDS no. 10-0319). ${ }^{30} \mathrm{CoFe}_{2} \mathrm{O}_{4} /$ CNTs were compared with standard spectra JCPDS no. 22$1086,{ }^{26}$ implying that $2 \theta$ values of $30.08^{\circ}, 35.44^{\circ}, 37.06^{\circ}, 43.06^{\circ}$, $53.45^{\circ}, 56.97^{\circ}$ and $62.59^{\circ}$ corresponded to (220), (311), (222), (400), (422), (511) and (440) facets of face-centered cubic spinel structure. The additional peak at around $26.06^{\circ}$ was assigned to (002) lattice plane of the CNTs. ${ }^{31}$ There was no obvious difference in ferrite diffraction peaks between $\mathrm{MFe}_{2} \mathrm{O}_{4}$ and $\mathrm{MFe}_{2} \mathrm{O}_{4}$ / CNTs.

The morphology and microstructure of the prepared $\mathrm{MFe}_{2} \mathrm{O}_{4} /$ CNTs was investigated by TEM (Fig. 2). Compared to unmodified CNTs (Fig. S1 in ESI $\dagger$ ), the $\mathrm{MFe}_{2} \mathrm{O}_{4}$ nanoparticles were randomly attached on the CNTs, and sizes of $\mathrm{MFe}_{2} \mathrm{O}_{4}$ were from 10 to $30 \mathrm{~nm}$. Fig. 3 displays the FT-IR spectra of the acidtreated CNTs and $\mathrm{MFe}_{2} \mathrm{O}_{4} / \mathrm{CNTs}$. The characteristic absorbance peak at $3442 \mathrm{~cm}^{-1}$ represents $-\mathrm{OH}$ group and at $1631 \mathrm{~cm}^{-1}$ corresponds to $-\mathrm{COOH}$ group. ${ }^{32}$ For $\mathrm{MFe}_{2} \mathrm{O}_{4} / \mathrm{CNTs}$ samples, the peak at $550-600 \mathrm{~cm}^{-1}$ was related to the metal-oxygen stretching mode from the ferrites. ${ }^{33}$ In addition, existing $2847-$ $2945 \mathrm{~cm}^{-1}$ (C-H stretching) peaks and bands at $1274 \mathrm{~cm}^{-1}$ and $715 \mathrm{~cm}^{-1}$ were related to stretching of $\mathrm{C}-\mathrm{O}$ bonds and metaloxygen deformation, respectively. ${ }^{34}$ The surface chemistry of

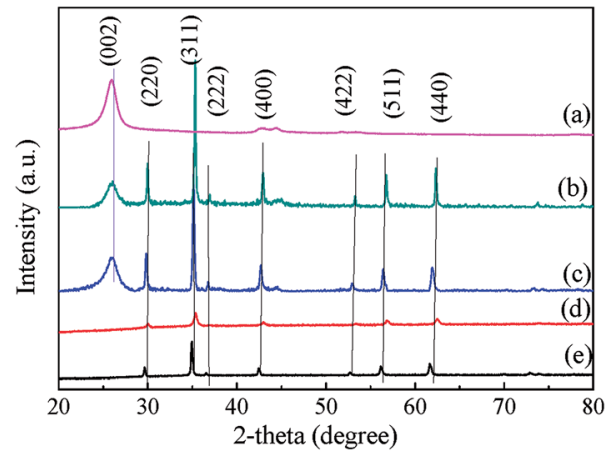

Fig. 1 XRD patterns of CNTs (a), $\mathrm{CoFe}_{2} \mathrm{O}_{4} / \mathrm{CNTs}$ (b), $\mathrm{MnFe}_{2} \mathrm{O}_{4} / \mathrm{CNTs}$ (c), $\mathrm{CoFe}_{2} \mathrm{O}_{4}$ (d) and $\mathrm{MnFe}_{2} \mathrm{O}_{4}(\mathrm{e})$.

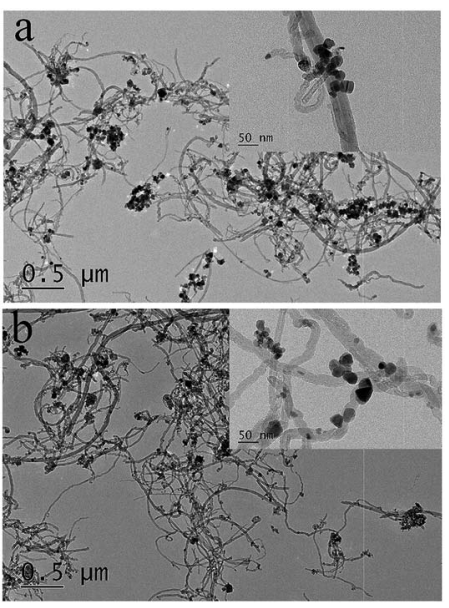

Fig. 2 TEM micrographs of $\mathrm{MnFe}_{2} \mathrm{O}_{4} / \mathrm{CNTs}(\mathrm{a})$ and $\mathrm{CoFe}_{2} \mathrm{O}_{4} / \mathrm{CNTs}(\mathrm{b})$.

$\mathrm{MFe}_{2} \mathrm{O}_{4} / \mathrm{CNTs}$ obtained by Boehm titration are summarized in Table S2, $\dagger$ which was consistent with FT-IR characterization. Relationship of $\Delta \mathrm{pH}$ (i.e. $\mathrm{pH}_{\text {final }}-\mathrm{pH}_{\text {initial }}$ ) and $\mathrm{pH}_{\text {initial }}$ was obtained in Fig. $\mathrm{S} 2, \dagger^{29}$ and the point of intersection gave the $\mathrm{pH}_{\mathrm{PZC}}$ of the $\mathrm{MnFe}_{2} \mathrm{O}_{4} / \mathrm{CNTs}$ and $\mathrm{CoFe}_{2} \mathrm{O}_{4} / \mathrm{CNTs}$ were $\sim 3.5$ and $\sim 4.0$, respectively.

To characterize the surface components and the elements valences of the composites, the materials were subjected to XPS analysis. The $\mathrm{C} 1 \mathrm{~s}, \mathrm{O}$ 1s, Mn 2p, Co $2 \mathrm{p}$ and Fe $2 \mathrm{p}$ core photoionization signals were shown in the XPS full spectrum scans (Fig. S3† and 4). The $\mathrm{C} 1 \mathrm{~s}$ characteristic peaks appearing at $284.5 \mathrm{eV}$ and $285.1 \mathrm{eV}$ are assigned to $\mathrm{C}-\mathrm{C}$ and $\mathrm{C}=\mathrm{C}$ bonds for CNTs, respectively. ${ }^{26,35}$ The $\mathrm{O} 1 \mathrm{~s}$ consist of three peaks that are assigned to $\mathrm{Fe}-\mathrm{O}\left(529.9 \mathrm{eV}\right.$ for $\mathrm{MnFe}_{2} \mathrm{O}_{4} / \mathrm{CNTs}$ and $529.8 \mathrm{eV}$ for $\left.\mathrm{CoFe}_{2} \mathrm{O}_{4} / \mathrm{CNTs}\right), \quad \mathrm{C}=\mathrm{O}\left(531.0 \mathrm{eV}\right.$ for $\mathrm{MnFe}_{2} \mathrm{O}_{4} / \mathrm{CNTs}$ and $531.6 \mathrm{eV}$ for $\left.\mathrm{CoFe}_{2} \mathrm{O}_{4} / \mathrm{CNTs}\right)$ and $\mathrm{C}-\mathrm{O}\left(533.0 \mathrm{eV}\right.$ for $\mathrm{MnFe}_{2} \mathrm{O}_{4} /$ CNTs and $533.1 \mathrm{eV}$ for $\mathrm{CoFe}_{2} \mathrm{O}_{4} / \mathrm{CNTs}$ ) bonds, ${ }^{36}$ indicating the introduction of new functional groups on the surfaces of $\mathrm{MFe}_{2} \mathrm{O}_{4} / \mathrm{CNTs}$ and consistency with the FT-IR analysis results. The Co 2p spectrum indicates Co existence in the $\mathrm{Co}^{2+}$ species, because the $\mathrm{Co}^{3+}$ cations can only be paired in weaker electron orbits. $^{37}$ The peaks of $\mathrm{Mn} 2 \mathrm{p}_{3 / 2}$ and $\mathrm{Mn} 2 \mathrm{p}_{1 / 2}$ individually appeared at 641.0 and $652.2 \mathrm{eV}$ referring to $\mathrm{Mn}$ (II), and Fe 2p at around $710.0 \mathrm{eV}$ signified the existence of $\mathrm{Fe}^{3+} \cdot 38,39$

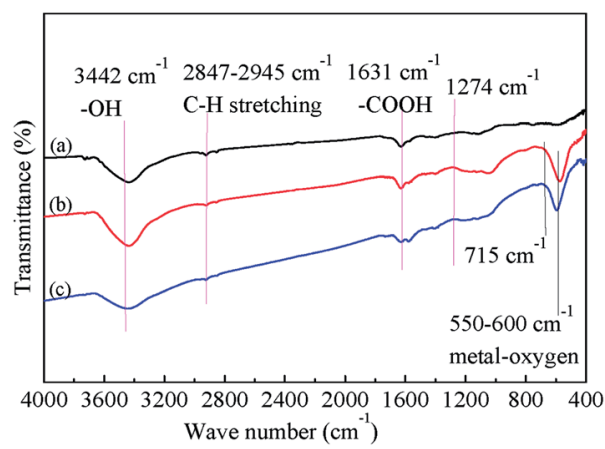

Fig. 3 FT-IR spectra of CNTs (a), $\mathrm{MnFe}_{2} \mathrm{O}_{4} / \mathrm{CNTs}(\mathrm{b})$ and $\mathrm{CoFe}_{2} \mathrm{O}_{4} /$ CNTs (c). 

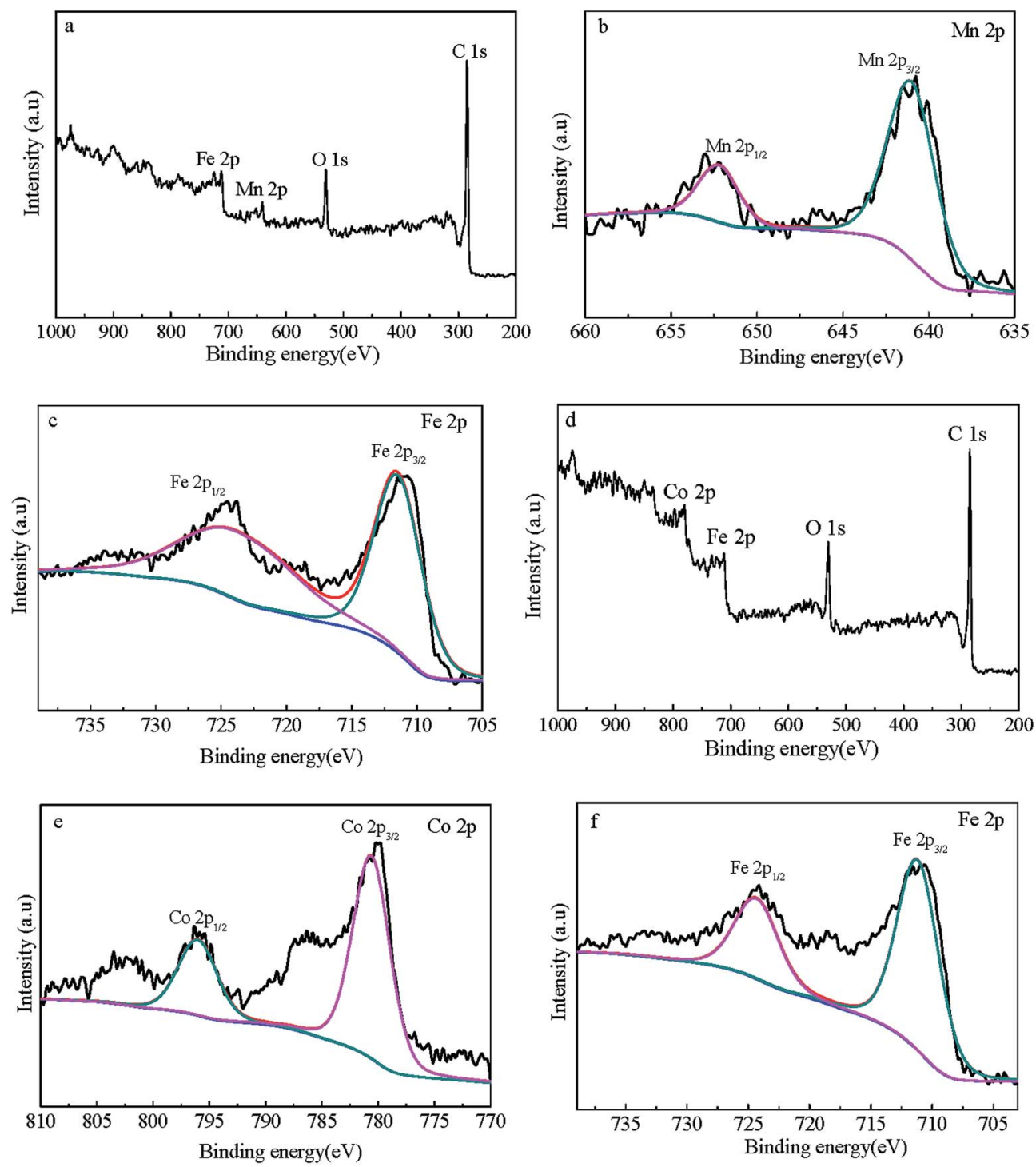

Fig. 4 XPS wide-scan (a), Mn 2p spectra (b) and Fe $2 p$ spectra (c) of $\mathrm{MnFe}_{2} \mathrm{O}_{4} / C N T s$; XPS wide-scan (d), Co 2p spectra (e) and Fe 2p spectra (f) of $\mathrm{CoFe}_{2} \mathrm{O}_{4} /$ CNTs.

Nitrogen adsorption-desorption isotherms of the adsorbents were H1-type hysteresis loops and the pore size was mainly mesopore distribution (Fig. 5), this indicates that the samples were mesoporous materials. ${ }^{40}$ Specific surface area, total pore volume and average pore size of the acid-treated CNTs and $\mathrm{MFe}_{2} \mathrm{O}_{4} / \mathrm{CNTs}$ are summarized in Table 1 . Compared to CNTs, these parameters were decreased for the $\mathrm{MFe}_{2} \mathrm{O}_{4} / \mathrm{CNTs}$. This phenomenon is in accordance with results in previous reports, which indicated that ferrite particles have much smaller surface area and pore volume as compared to CNTs. ${ }^{26}$ TG curves (Fig. 6) clearly show that the mass fractions were finally maintained at $52.5 \%$ for $\mathrm{MnFe}_{2} \mathrm{O}_{4} / \mathrm{CNTs}$ and $47.5 \%$ for $\mathrm{CoFe}_{2} \mathrm{O}_{4} / \mathrm{CNTs}$, respectively. Peaks at $480-510{ }^{\circ} \mathrm{C}$ on DSC traces indicate that $\mathrm{MFe}_{2} \mathrm{O}_{4} / \mathrm{CNTs}$ were thermally stable until the temperature reached over $480{ }^{\circ} \mathrm{C}$. The saturation magnetization of $\mathrm{MnFe}_{2} \mathrm{O}_{4} / \mathrm{CNTs}$ and $\mathrm{CoFe}_{2} \mathrm{O}_{4} / \mathrm{CNTS}$ were 23.8 and $26.1 \mathrm{emu} \mathrm{g}^{-1}$, respectively (Fig. 7). It was reported that the composite with a saturation magnetization over $16.3 \mathrm{emu} \mathrm{g}^{-1}$ had a strong magnetic response capability. ${ }^{38}$ Therefore, the prepared $\mathrm{MnFe}_{2} \mathrm{O}_{4} / \mathrm{CNTs}$ could be magnetically separated from wastewater, which was verified by a direct magnetic experiment (photo in Fig. 7).

\subsection{Adsorption and desorption performances}

As shown in Fig. 8, the adsorption tendencies were similar for various adsorbents. The BZF was rapidly adsorbed within the initial $2 \mathrm{~min}$, and then it continued at a relatively smaller adsorption rate and finally achieved equilibrium at around $20 \mathrm{~min}$. This observation is consistent with the results in literatures. ${ }^{23,40}$ For adsorbents with a large amount of surface active sites, initial surface diffusion between the solid phase and the liquid phase was fast. ${ }^{41}$ The following slower adsorption rate was related to intraparticle diffusion that affected the overall adsorption time. $\mathrm{MnFe}_{2} \mathrm{O}_{4}$ and $\mathrm{CoFe}_{2} \mathrm{O}_{4}$ were inefficient for adsorptive 

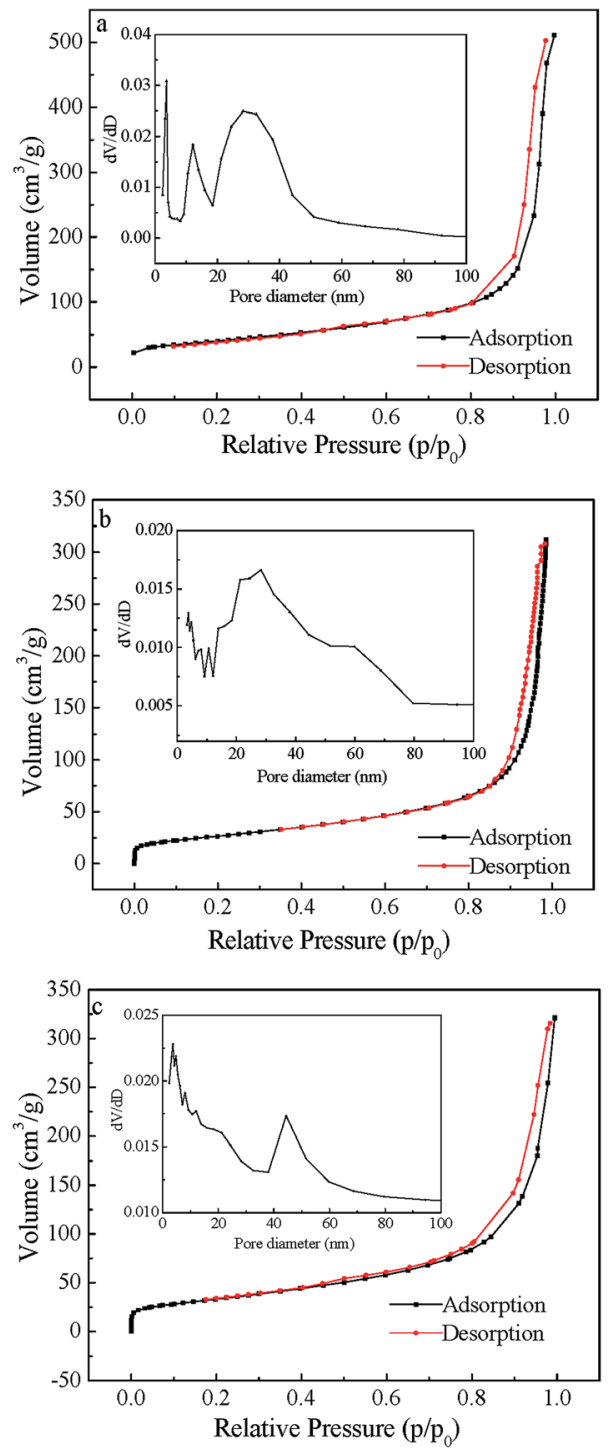

Fig. 5 Nitrogen adsorption-desorption isotherms of CNTs (a), $\mathrm{MnFe}_{2} \mathrm{O}_{4} / \mathrm{CNTs}$ (b) and $\mathrm{CoFe}_{2} \mathrm{O}_{4} / \mathrm{CNTs}$ (c). (The inset shows the pore size distribution curves).

Table 1 The physical properties of CNTs and $\mathrm{MFe}_{2} \mathrm{O}_{4} / \mathrm{CNTS}$

\begin{tabular}{lcll}
\hline Material & $\begin{array}{l}S_{\mathrm{BET}} \\
\left(\mathrm{m}^{2} \mathrm{~g}^{-1}\right)\end{array}$ & $\begin{array}{l}V_{\text {total }} \\
\left(\mathrm{cm}^{3} \mathrm{~g}^{-1}\right)\end{array}$ & $\begin{array}{l}\text { Average pore } \\
\text { size }(\mathrm{nm})\end{array}$ \\
\hline $\mathrm{CNTs}$ & & & \\
$\mathrm{MnFe}_{2} \mathrm{O}_{4} / \mathrm{CNTs}$ & 145.92 & 0.7618 & 20.883 \\
$\mathrm{CoFe}_{2} \mathrm{O}_{4} / \mathrm{CNTs}$ & 96.526 & 0.4827 & 20.003 \\
& 120.67 & 0.4647 & 15.405
\end{tabular}

removal of BZF. Although the adsorption capacity of CNTs decreased after ferrite modification, the $\mathrm{MFe}_{2} \mathrm{O}_{4} / \mathrm{CNTS}$ also showed to be effective for BZF removal, the maximum adsorption capacities of $\mathrm{MnFe}_{2} \mathrm{O}_{4} / \mathrm{CNTs}$ and $\mathrm{CoFe}_{2} \mathrm{O}_{4} / \mathrm{CNTs}$ for BZF were 30.1 and $24.5 \mathrm{mg} \mathrm{g}^{-1}$, respectively. Compared to $\mathrm{CoFe}_{2} \mathrm{O}_{4} / \mathrm{CNTs}$, $\mathrm{MnFe}_{2} \mathrm{O}_{4} / \mathrm{CNTs}$ had a smaller specific surface area but exhibited a higher BZF adsorption capacity, implying that the surface
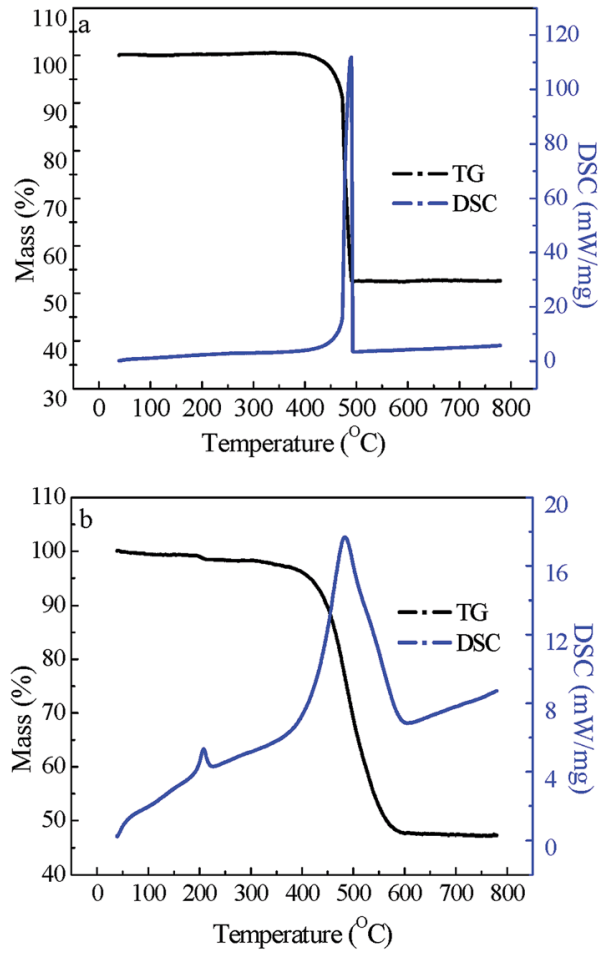

Fig. 6 TG-DSC curves of $\mathrm{MnFe}_{2} \mathrm{O}_{4} / \mathrm{CNTs}(\mathrm{a})$ and $\mathrm{CoFe}_{2} \mathrm{O}_{4} / \mathrm{CNTs}(\mathrm{b})$.

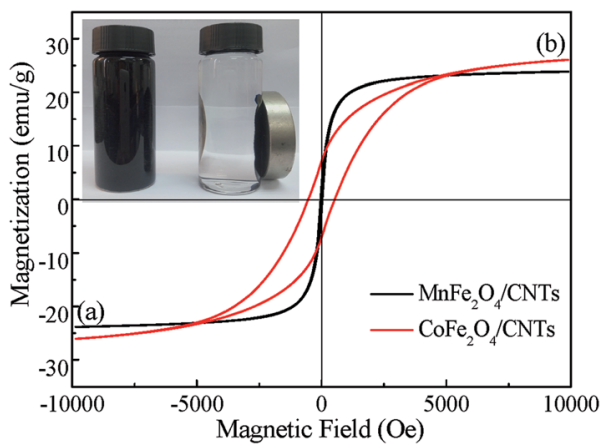

Fig. $7 \mathrm{M}-\mathrm{H}$ hysteresis loops of $\mathrm{MnFe}_{2} \mathrm{O}_{4} / \mathrm{CNTs}$ (a) and $\mathrm{CoFe}_{2} \mathrm{O}_{4} /$ CNTs (b). (The inset shows the magnetic characterization of $\mathrm{MFe}_{2} \mathrm{O}_{4} /$ CNTs via an external magnetic field).

functional groups, the active surface sites and particle size might also be influence factors for adsorption capacities. A similar inference was suggested by previous reports. ${ }^{28,42}$

Fig. 9 shows the effects of initial BZF concentration on the adsorption efficiency of the $\mathrm{MFe}_{2} \mathrm{O}_{4} / \mathrm{CNTs}$. When the initial BZF concentration varied from 5 to $40 \mathrm{mg} \mathrm{L}^{-1}$, the maximum adsorption capacities of $\mathrm{MnFe}_{2} \mathrm{O}_{4} / \mathrm{CNTs}$ and $\mathrm{CoFe}_{2} \mathrm{O}_{4} / \mathrm{CNTs}$ for BZF increased from 14.8 to $33.4 \mathrm{mg} \mathrm{g}^{-1}$ and 8.1 to $27.8 \mathrm{mg} \mathrm{g}^{-1}$, respectively. The initial concentration of BZF had a great influence on the saturated adsorption capacity of $\mathrm{MFe}_{2} \mathrm{O}_{4} /$ CNTs.

Besides the adsorption performance, the recycling and reuse ability of the adsorbent are also important for its application. Methanol was used as the desorption agent due to its weak polarity. ${ }^{43}$ The calculated desorption efficiencies of the 


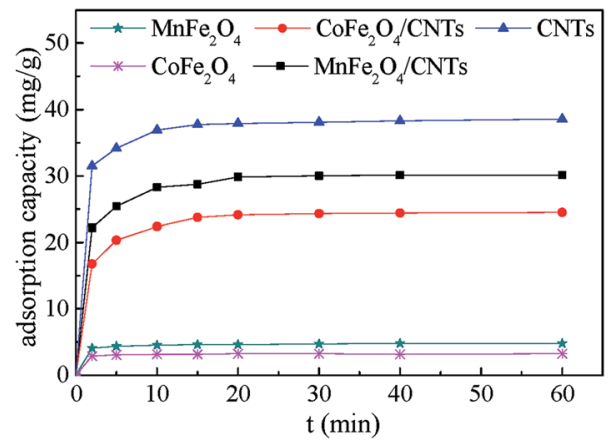

Fig. 8 Adsorption capacity of various adsorbents. (Initial BZF concentration $20 \mathrm{mg} \mathrm{L}^{-1}$, adsorbent dosage $0.02 \mathrm{~g}$, neutral $\mathrm{pH}$ and temperature $25^{\circ} \mathrm{C}$ ).
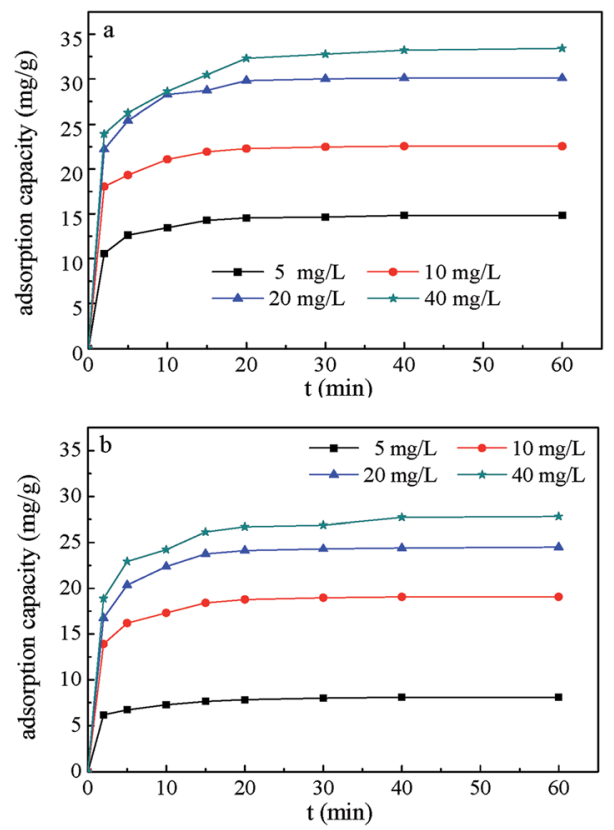

Fig. 9 Effects of initial BZF concentration on the adsorption efficiency of $\mathrm{MnFe}_{2} \mathrm{O}_{4} / \mathrm{CNTS}$ (a) and $\mathrm{CoFe}_{2} \mathrm{O}_{4} / \mathrm{CNTs}$ (b). (Adsorbent dosage $0.02 \mathrm{~g}$, neutral $\mathrm{pH}$ and temperature $25^{\circ} \mathrm{C}$ ).

$\mathrm{MnFe}_{2} \mathrm{O}_{4} / \mathrm{CNTs}$ and $\mathrm{CoFe}_{2} \mathrm{O}_{4} / \mathrm{CNTs}$ were $82.4 \%$ and $76.0 \%$, respectively, confirming a good desorption performance of $\mathrm{MFe}_{2} \mathrm{O}_{4} /$ CNTs.

\subsection{Adsorption isotherms}

The Langmuir and Freundlich isotherms, two commonly used adsorption isotherm models, ${ }^{\mathbf{4 4 , 4 5}}$ were fitted to explore the interaction between the adsorbents and contaminant (eqn (3) and (4)).

$$
\begin{gathered}
\frac{1}{q_{\mathrm{e}}}=\frac{1}{q_{\max }}+\frac{1}{K_{\mathrm{L}} q_{\max }} \frac{1}{C_{\mathrm{e}}} \\
\log q_{\mathrm{e}}=\log K_{\mathrm{F}}+\frac{1}{n} \log C_{\mathrm{e}}
\end{gathered}
$$
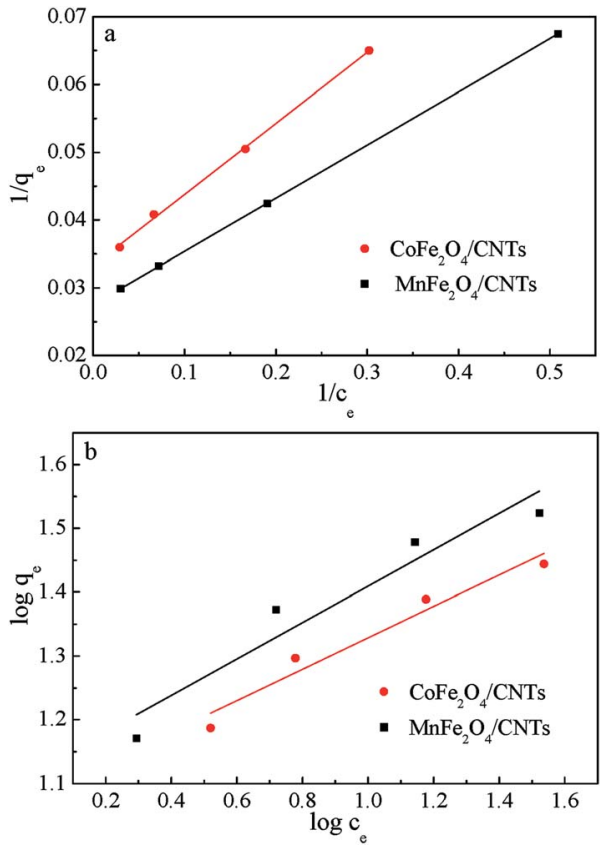

Fig. 10 Adsorption isotherm models of BZF: Freundlich (a) and Langmuir (b). (Adsorbent dosage $0.02 \mathrm{~g}$, neutral $\mathrm{pH}$ and temperature $\left.25^{\circ} \mathrm{C}\right)$.

where $q_{\mathrm{e}}$ is the amount of BZF adsorbed per unit mass of the $\mathrm{MFe}_{2} \mathrm{O}_{4} / \mathrm{CNTs}, \mathrm{mg} \mathrm{g}^{-1} ; q_{\max }$ is the maximum adsorption capacity, $\mathrm{mg} \mathrm{g}^{-1} ; C_{\mathrm{e}}$ is the aqueous equilibrium concentration of $\mathrm{BZF}, \mathrm{mg} \mathrm{L}^{-1} ; K_{\mathrm{L}}$ is the Langmuir adsorption affinity parameter, $\mathrm{L} \mathrm{mg}^{-1} . K_{\mathrm{F}}$ and $1 / n$ are the Freundlich isotherm constants.

Fig. 10 shows the Langmuir and Freundlich isotherms based on the experimental data, and the parameters calculated from linear regression are listed in Table 2 . The maximum adsorption capacities toward BZF calculated by Langmuir equation were $35.5 \mathrm{mg} \mathrm{g}^{-1}$ for $\mathrm{MnFe}_{2} \mathrm{O}_{4} / \mathrm{CNTs}$ and $29.1 \mathrm{mg} \mathrm{g}^{-1}$ for $\mathrm{CoFe}_{2} \mathrm{O}_{4} /$ CNTs, and the correlation coefficients $\left(R^{2}\right)$ of the Langmuir model are over 0.99. These results suggest that $\mathrm{MFe}_{2} \mathrm{O}_{4} / \mathrm{CNTs}$ have great potential for BZF removal and the Langmuir isotherm fits the experimental data better than Freundlich isotherm. The Langmuir isotherm implies that a monolayer-type adsorption of BZF onto the sorption sites of $\mathrm{MFe}_{2} \mathrm{O}_{4} / \mathrm{CNTs}^{40}$

The Dubinin-Radushkevich isotherm was applied to express the adsorption mechanism and distinguish the physical and chemical adsorption of BZF on $\mathrm{MFe}_{2} \mathrm{O}_{4} /$ CNTs with its mean free energy. ${ }^{\mathbf{4 6 , 4 7}}$ The calculated sorption means free energy for the $\mathrm{MnFe}_{2} \mathrm{O}_{4} / \mathrm{CNTs}$ and $\mathrm{CoFe}_{2} \mathrm{O}_{4} /$ CNTs from the Dubinin-Radushkevich isotherm were 4.6 and $4.5 \mathrm{~kJ} \mathrm{~mol}^{-1}$, respectively (Table $\mathrm{S} 3 \dagger)$, indicating multiple adsorption interactions such as van der Waals, hydrogen and $\pi-\pi$ bonding may mainly affect the adsorption mechanism. ${ }^{48}$

\subsection{Adsorption kinetics}

3.4.1 Pseudo-first-order and pseudo-second-order models. The pseudo-first-order (eqn (5)) and pseudo-second-order (eqn (6)) kinetic models were suitably applied to analyze the process of magnetic ferrite adsorption. ${ }^{37}$ 
Table 2 Parameters of Freundlich and Langmuir adsorption isotherm models for BZF adsorption on $\mathrm{MFe}_{2} \mathrm{O}_{4} / \mathrm{CNTs}$. (Adsorbent dosage $0.02 \mathrm{~g}$, neutral $\mathrm{pH}$ and temperature $25^{\circ} \mathrm{C}$ )

\begin{tabular}{|c|c|c|c|c|c|c|}
\hline \multirow[b]{2}{*}{ Adsorbent } & \multicolumn{3}{|c|}{ Langmuir model } & \multicolumn{3}{|c|}{ Freundlich model } \\
\hline & $q_{\max }\left(\mathrm{mg} \mathrm{g}^{-1}\right)$ & $K_{\mathrm{L}}\left(\mathrm{L} \mathrm{mg}^{-1}\right)$ & $R_{\mathrm{L}}^{2}$ & $K_{\mathrm{F}}$ & $n$ & $R_{\mathrm{F}}^{2}$ \\
\hline $\mathrm{MnFe}_{2} \mathrm{O}_{4} / \mathrm{CNTs}$ & 35.5 & 0.3606 & 0.9999 & 3.04 & 3.43 & 0.9298 \\
\hline $\mathrm{CoFe}_{2} \mathrm{O}_{4} / \mathrm{CNTs}$ & 29.1 & 0.3340 & 0.9983 & 2.91 & 3.94 & 0.9574 \\
\hline
\end{tabular}

Table 3 Adsorption parameters got from kinetic for the adsorption of BZF on $\mathrm{MFe}_{2} \mathrm{O}_{4} / \mathrm{CNTS}$. (Initial BZF concentration 20 mg L ${ }^{-1}$, adsorbent dosage $0.02 \mathrm{~g}$, neutral $\mathrm{pH}$ and temperature $25^{\circ} \mathrm{C}$ )

\begin{tabular}{|c|c|c|c|c|c|c|}
\hline Adsorbent & $K_{1}(1 / \mathrm{min})$ & $q_{\mathrm{e}}\left(\mathrm{mg} \mathrm{g}^{-1}\right)$ & $R_{1}{ }^{2}$ & $K_{2}\left(\mathrm{~g}(\mathrm{mg} \min )^{-1}\right)$ & $q_{\mathrm{e}}\left(\mathrm{mg} \mathrm{g}^{-1}\right)$ & $R_{2}^{2}$ \\
\hline $\mathrm{CoFe}_{2} \mathrm{O}_{4} / \mathrm{CNTs}$ & 0.2701 & 6.60 & 0.9737 & 0.0427 & 25.00 & 0.9999 \\
\hline
\end{tabular}

$$
\begin{gathered}
\log \left(q_{\mathrm{e}}-q_{t}\right)=\log q_{\mathrm{e}}-\frac{K_{1} t}{2.303} \\
\frac{t}{q_{t}}=\frac{1}{K_{2} q_{\mathrm{e}}^{2}}+\frac{t}{q_{\mathrm{e}}}
\end{gathered}
$$

where $q_{\mathrm{e}}$ and $q_{t}$ are the amount of BZF adsorbed at equilibrium and at time $(t)$, respectively, $\mathrm{mg} \mathrm{g}^{-1} ; K_{1}(1 / \mathrm{min})$ and $K_{2}$ $\left(\mathrm{g}(\mathrm{mg} \mathrm{min})^{-1}\right)$ are the pseudo-first-and second-order rate constant, respectively.
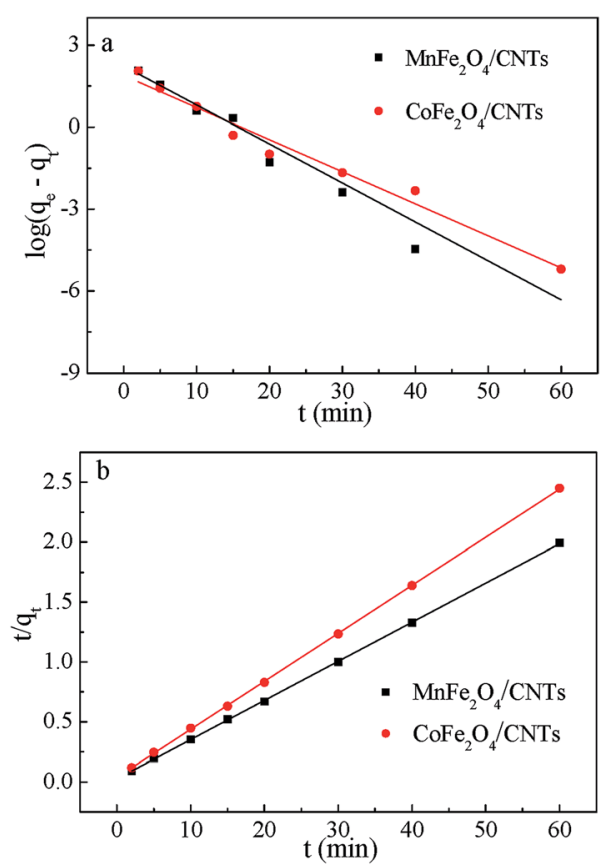

Fig. 11 Kinetic curves of BZF adsorption on $\mathrm{MFe}_{2} \mathrm{O}_{4} / \mathrm{CNTS}$ : Pseudofirst-order model (a) and Pseudo-second-order model (b). (Initial BZF concentration $20 \mathrm{mg} \mathrm{L}^{-1}$, adsorbent dosage $0.02 \mathrm{~g}$, neutral $\mathrm{pH}$ and temperature $25^{\circ} \mathrm{C}$ ).
The calculated data (Table 3 and Fig. 11) reveal that the higher correlation coefficients $\left(R^{2}\right)$ of the pseudo-second-order model was over 0.99 , and the calculated $q_{\mathrm{e}}$ values were consistent better with experimental values, as compared to the pseudo-first-order model. A better agreement with pseudosecond-order model indicates that the adsorption mechanism depended on the $\mathrm{MFe}_{2} \mathrm{O}_{4} / \mathrm{CNTS}$ and BZF molecule. ${ }^{23,49}$

3.4.2 Weber and Morris model. The Weber and Morris model could be used to assess and differentiate the effect of the boundary layer and intraparticle diffusion on adsorption progress. ${ }^{50}$ It can be described as eqn (7).

$$
q_{t}=K_{\mathrm{WM}} \sqrt{t}+L
$$

where $q_{t}$ is the amount of BZF adsorbed on the adsorbent at the time $(t), \mathrm{mg} \mathrm{g}^{-1} ; K_{\mathrm{WM}}$ is the internal diffusion coefficient; $t$ is the adsorption time, $\min ; L$ is the thickness of the boundary layer.

The results in Fig. 12 show that the straight lines did not pass through the origin and values of $R^{2}$ were less than 0.66 , indicating that the internal diffusion model could not fully fit the adsorption process, and internal diffusion was not the only factor controlling the adsorption process. ${ }^{51}$ The boundary layer effect of $\mathrm{MnFe}_{2} \mathrm{O}_{4} / \mathrm{CNTs}$ was greater than that of $\mathrm{CoFe}_{2} \mathrm{O}_{4} / \mathrm{CNTs}$ according to the intercept value. In general, as the boundary layer increased, the surface flux increased too, allowing a faster adsorption of BZF molecules towards the inside of the $\mathrm{MFe}_{2} \mathrm{O}_{4} /$ CNTs pores. This phenomenon is consistent with the actual adsorption process from the straight slopes in Fig. 8 and 9.

3.4.3 Boyd model. The adsorption process was found to be controlled by external mass transfer and intra-particle diffusion, thus, the actual rate-controlling step was further analyzed by Boyd model. ${ }^{52}$ The kinetic model expression can be written as follows. ${ }^{53}$

$$
\mathrm{Bt}=-0.4977-\ln \left(1-\frac{q_{t}}{q_{\mathrm{e}}}\right)
$$




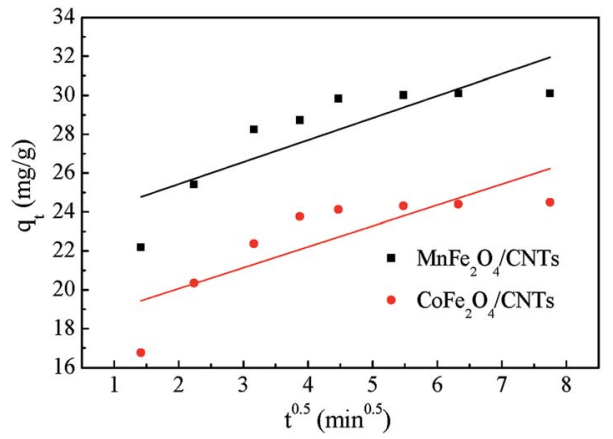

Fig. 12 Weber and Morris kinetic model of BZF adsorption on $\mathrm{MFe}_{2} \mathrm{O}_{4} / \mathrm{CNTs}$. (Initial BZF concentration $20 \mathrm{mg} \mathrm{L}^{-1}$, adsorbent dosage $0.02 \mathrm{~g}$, neutral $\mathrm{pH}$ and temperature $25^{\circ} \mathrm{C}$ ).

$$
B=\frac{\pi^{2} D_{\mathrm{i}}}{r^{2}}
$$

where $q_{\mathrm{e}}$ and $q_{t}$ are the amount of BZF adsorbed at equilibrium and at time $(t)$, respectively, $\mathrm{mg} \mathrm{g}^{-1} ; D_{\mathrm{i}}\left(\mathrm{cm}^{2} \mathrm{~s}^{-1}\right)$ are the effective diffusion coefficient and $r$ represents the radius of adsorbent particles assumed to be spherical.

The linearity test of Bt $v s$. $t$ plots were employed to find out the particle diffusion control mechanism. Fig. 13 shows the plots of $\mathrm{MFe}_{2} \mathrm{O}_{4} / \mathrm{CNTs}$ were linear and did not pass through the origin, indicating that external mass transfer mainly affected the rate-controlling process and intraparticle diffusion showed a relatively weak rate control for $\mathrm{BZF}$ adsorption onto $\mathrm{MFe}_{2} \mathrm{O}_{4} /$ CNTs. These results were in good agreement with the analysis of Weber and Morris model and a similar control mechanism had been reported by Kumar et al. ${ }^{\mathbf{5 4}}$

\subsection{Adsorption thermodynamics}

The feasibility of the adsorption process was also evaluated by thermodynamics analysis. Gibbs free energy $\left(\Delta G^{\mathrm{o}}\right)$ using the following equation (eqn (10)) and $K_{\mathrm{d}}$ was the distribution constant calculated by eqn (11). ${ }^{55}$

$$
\Delta G^{\mathrm{o}}=-R T \ln K_{\mathrm{d}}
$$

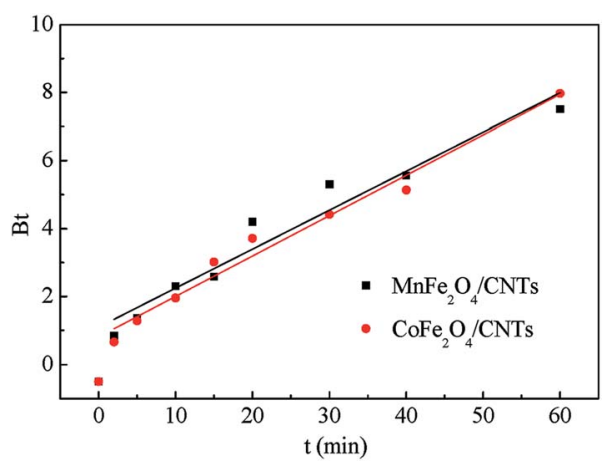

Fig. 13 Boyd model of BZF adsorption on $\mathrm{MFe}_{2} \mathrm{O}_{4} / \mathrm{CNTS}$. (Initial BZF concentration $20 \mathrm{mg} \mathrm{L}^{-1}$, adsorbent dosage $0.02 \mathrm{~g}$, neutral $\mathrm{pH}$ and temperature $25^{\circ} \mathrm{C}$ ).

$$
K_{\mathrm{d}}=\frac{q_{\mathrm{e}}}{C_{\mathrm{e}}}
$$

where $R$ is the universal gas constant $\left(8.314 \times 10^{-3} \mathrm{~kJ}(\mathrm{~mol} \mathrm{~K})^{-1}\right)$; $T$ is $298 \mathrm{~K} ; q_{\mathrm{e}}$ is the amount of BZF adsorbed on the $\mathrm{MFe}_{2} \mathrm{O}_{4} / \mathrm{CNTs}, \mathrm{mg} \mathrm{g}^{-1} ; C_{\mathrm{e}}$ is equilibrium concentration of BZF in the solution, $\mathrm{mg} \mathrm{L}^{-1}$.

With the initial BZF concentration of $20 \mathrm{mg} \mathrm{L}^{-1}, \Delta G^{\mathrm{O}}$ of BZF adsorbed on the $\mathrm{MFe}_{2} \mathrm{O}_{4} / \mathrm{CNTs}$ were negative values, suggesting that the adsorption processes were spontaneous. The greater the $\Delta G^{\mathrm{o}}$, the smaller the spontaneous trend. ${ }^{56}$ The calculated $\Delta G^{\mathrm{o}}$ for the $\mathrm{MnFe}_{2} \mathrm{O}_{4} /$ CNTs and $\mathrm{CoFe}_{2} \mathrm{O}_{4} /$ CNTs were -1.9 and $-1.2 \mathrm{~kJ} \mathrm{~mol}^{-1}$, displaying that the adsorption process of the $\mathrm{MnFe}_{2} \mathrm{O}_{4} /$ CNTs was more spontaneous than the $\mathrm{CoFe}_{2} \mathrm{O}_{4} /$ CNTs.

\subsection{Adsorption mechanism}

Generally, the adsorption mechanisms of the aqueous organic pollutants on ferrites and carbon-based porous adsorbents involve the surface diffusion, pore diffusion and adsorption reactions. ${ }^{50,57}$ Although the mechanism of BZF adsorbed on the $\mathrm{MFe}_{2} \mathrm{O}_{4} / \mathrm{CNTS}$ is not yet clear, several points could be raised in order to discuss the adsorption process. It is reported that the specific surface area, surface functional group and boundary layer jointly affect the performance of the adsorption site, thereby affecting the surface diffusion. ${ }^{41}$ The BET and FT-IR analyses (Table 1 and Fig. 3) indicate that ferrite modification changed the specific surface area and surface functional groups of the CNTs. However, the comparison tests (Fig. 8) imply that the introduced ferrite did not dominate the BZF adsorption on the $\mathrm{MFe}_{2} \mathrm{O}_{4} / \mathrm{CNTs}$, and the process might be mainly determined by the CNTs. The Langmuir model suggests the applicability of monolayer coverage of BZF molecules on the surface of $\mathrm{MFe}_{2} \mathrm{O}_{4} /$ CNTs. Surface diffusion governs the surface flux of BZF, having a significant effect on the overall intraparticle diffusion. On the other hand, based on the results of the pore size distribution (Fig. 5) and the Weber and Morris model (Fig. 12), it can be speculated that the pore diffusion is mainly controlled by the porosity, adsorption sites within the pores, and blocking effect. The adsorption reactions occur at the adsorption site, through the entire adsorption process, being a dynamic balancing process. In summary, the amount of adsorbent surface and internal adsorption site determines the amount of adsorption, while the porosity and the properties of the surface layer

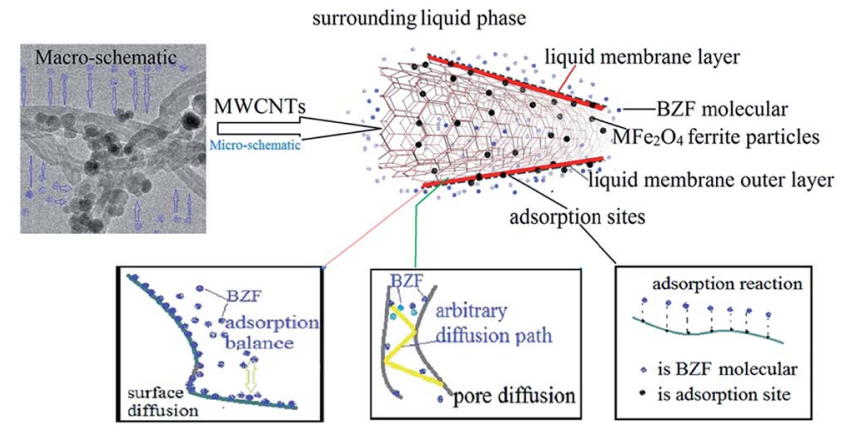

Fig. 14 Possible mechanism of BZF adsorption on $\mathrm{MFe}_{2} \mathrm{O}_{4} / \mathrm{CNTS}$. 
determine the adsorption rate. The possible adsorption mechanism is shown in Fig. 14.

It should be noted that the results of this study were obtained with synthetic BZF solutions. The determined $\mathrm{pH}_{\mathrm{PZC}}$ values for $\mathrm{MFe}_{2} \mathrm{O}_{4} / \mathrm{CNTs}$ were lower than the $\mathrm{pH}$ of the current reaction solution $(\sim 7.0)$. This fact suggests negative charge exists on the surface of $\mathrm{MFe}_{2} \mathrm{O}_{4} / \mathrm{CNTs}$, promoting cationic adsorption during the adsorption process. ${ }^{24,58}$ In addition, $\log K_{\mathrm{ow}}$ and $\log K_{\mathrm{oc}}$ of BZF are 4.25 and 1.0 at $\mathrm{pH}=7.4,{ }^{59}$ respectively, indicating that BZF has a high tendency to sorb onto the organic material. For practical application, the water matrix such as $\mathrm{pH}$ and organic carbon content, may have significant effects on BZF adsorption. Due to the complex compositions of real water or wastewaters, more studies are required to further elucidate the adsorption behavior and mechanism.

\section{Conclusions}

The mesoporous $\mathrm{MFe}_{2} \mathrm{O}_{4} / \mathrm{CNTs}$ with large surface area and good dispersity were synthesized for the adsorptive removal of BZF. Characterization results in conjunction with experimental data demonstrated the high efficiency and recyclability of the fabricated $\mathrm{MFe}_{2} \mathrm{O}_{4} / \mathrm{CNTs}$. Restated, not only BZF containing wastewater could be purified, but also the used adsorbents could be easily magnetically separated and regenerated. The spontaneous adsorption processes could be well described by Langmuir isotherm model and pseudo-second-order equation. The porosity and adsorption sites within pores had a synergistic effect on the rate of pore diffusion, and the amount of adsorption site would substantially affect the saturated adsorption.

\section{Conflicts of interest}

The authors declare no competing financial interest.

\section{Acknowledgements}

We are grateful for grants from the National Natural Science Foundation of China (No. 51608167), Scientific and Technological Project of Henan Province (No. 162102310057), and A Project Funded by the Priority Academic Program Development of Jiangsu Higher Education Institutions.

\section{References}

1 J. Wang and S. Wang, J. Environ. Manage., 2016, 182, 620640.

2 J.-L. Liu and M.-H. Wong, Environ. Int., 2013, 59, 208-224.

3 C. I. Kosma, D. A. Lambropoulou and T. A. Albanis, Sci. Total Environ., 2014, 466, 421-438.

4 Z. Li, X. Xiang, M. Li, Y. Ma, J. Wang and X. Liu, Ecotoxicol. Environ. Saf., 2015, 119, 74-80.

5 F. O. Agunbiade and B. Moodley, Environ. Toxicol. Chem., 2016, 35, 36-46.

6 I. Zaibel, D. Zilberg, L. Groisman and S. Arnon, Sci. Total Environ., 2016, 559, 268-281.
7 Y. M. Velasco-Santamaría, B. Korsgaard, S. S. Madsen and P. Bjerregaard, Aquat. Toxicol., 2011, 105, 107-118.

8 T. Malchi, Y. Maor, G. Tadmor, M. Shenker and B. Chefetz, Environ. Sci. Technol., 2014, 48, 9325-9333.

9 H. Yuan, Y. Zhang and X. Zhou, Clean: Soil, Air, Water, 2012, 40, 239-245.

10 M. M. Huber, S. Canonica, G.-Y. Park and U. Von Gunten, Environ. Sci. Technol., 2003, 37, 1016-1024.

11 D. Wu, R. Zhang, G. Lu, Q. Lin, F. Liu and Y. Li, Clean: Soil, Air, Water, 2017, 45, 1500664.

12 D. Wu, G. Lu, R. Zhang, H. You, Z. Yan and Y. Li, Water Sci. Technol.: Water Supply, 2016, 16, 163-170.

13 C. Gadipelly, A. Pérez-González, G. D. Yadav, I. Ortiz, R. Ibáñez, V. K. Rathod and K. V. Marathe, Ind. Eng. Chem. Res., 2014, 53, 11571-11592.

14 A. Carmalin Sophia, E. C. Lima, N. Allaudeen and S. Rajan, Desalin. Water Treat., 2016, 57, 27573-27586.

15 J. He, K. Chen, X. Cai, Y. Li, C. Wang, K. Zhang, Z. Jin, F. Meng, X. Wang and L. Kong, J. Colloid Interface Sci., 2017, 490, 97-107.

16 F. Yu, Y. Li, S. Han and J. Ma, Chemosphere, 2016, 153, 365385.

17 N. Zhuo, Y. Lan, W. Yang, Z. Yang, X. Li, X. Zhou, Y. Liu, J. Shen and X. Zhang, Sep. Purif. Technol., 2017, 177, 272280.

18 T. M. Salem Attia, X. L. Hu and D. Q. Yin, Chemosphere, 2013, 93, 2076-2085.

19 W. Chen, X. Li, Z. Pan, Y. Bao, S. Ma and L. Li, Chem. Eng. J., 2015, 281, 397-403.

20 Z. Chen, D. Pierre, H. He, S. Tan, C. Pham-Huy, H. Hong and J. Huang, Int. J. Pharm., 2011, 405, 153-161.

21 F. Yu, J. Chen, L. Chen, J. Huai, W. Gong, Z. Yuan, J. Wang and J. Ma, J. Colloid Interface Sci., 2012, 378, 175-183.

22 Z. Yan, G. Lu, H. Sun and B. Ma, Chemosphere, 2017, 178, 165-172.

23 L. Wang, J. Li, Y. Wang, L. Zhao and Q. Jiang, Chem. Eng. J., 2012, 181, 72-79.

24 O. A. Oyetade, V. O. Nyamori, B. S. Martincigh and S. B. Jonnalagadda, RSC Adv., 2015, 5, 22724-22739.

25 W. Sun, W. Pan, F. Wang and N. Xu, Chem. Eng. J., 2015, 273, 353-362.

26 L. Tan, Q. Liu, X. Jing, J. Liu, D. Song, S. Hu, L. Liu and J. Wang, Chem. Eng. J., 2015, 273, 307-315.

27 D. Wu, G. Lu, R. Zhang, Q. Lin, J. Yao, X. Shen and W. Wang, Electrochim. Acta, 2017, 236, 297-306.

28 X. Bao, Z. Qiang, W. Ling and J.-H. Chang, Sep. Purif. Technol., 2013, 117, 104-110.

29 O. A. Oyetade, V. O. Nyamori, B. S. Martincigh and S. B. Jonnalagadda, $R S C A d v ., 2016,6,2731-2745$.

30 M. Balaji, R. Jeyaram and P. Matheswaran, J. Alloys Compd., 2017, 696, 435-442.

31 L. Zhou, L. Ji, P.-C. Ma, Y. Shao, H. Zhang, W. Gao and Y. Li, J. Hazard. Mater., 2014, 265, 104-114.

32 X. Zhang, M. Feng, R. Qu, H. Liu, L. Wang and Z. Wang, Chem. Eng. J., 2016, 301, 1-11.

33 D. Berger, D. Georgescu, L. Bajenaru, A. Zanfir, N. Stănică and C. Matei, J. Alloys Compd., 2017, 708, 278-284. 
34 A. Esmaeili and S. Ghobadianpour, Ind. Crops Prod., 2016, 91, 44-48.

35 C.-C. Chen, C.-F. Chen, C.-M. Chen and F.-T. Chuang, Electrochem. Commun., 2007, 9, 159-163.

36 J. Ma, Z. Zhu, B. Chen, M. Yang, H. Zhou, C. Li, F. Yu and J. Chen, J. Mater. Chem. A, 2013, 1, 4662-4666.

37 N. Li, M. Zheng, X. Chang, G. Ji, H. Lu, L. Xue, L. Pan and J. Cao, J. Solid State Chem., 2011, 184, 953-958.

38 C. Tan, N. Gao, D. Fu, J. Deng and L. Deng, Sep. Purif. Technol., 2017, 175, 47-57.

39 A. S. Albuquerque, M. V. C. Tolentino, J. D. Ardisson, F. C. C. Moura, R. D. Mendonça and W. A. A. Macedo, Ceram. Int., 2012, 38, 2225-2231.

40 Q. Hu, Y. Liu, X. Gu and Y. Zhao, Chemosphere, 2017, 181, 328-336.

41 R. Ocampo-Perez, C. G. Aguilar-Madera and V. Díaz-Blancas, Chem. Eng. J., 2017, 321, 510-520.

42 S. Mishra, J. Dwivedi, A. Kumar and N. Sankararamakrishnan, RSC Adv., 2016, 6, 95865-95878.

43 M. J. Ahmed and M. Ahmaruzzaman, J. Environ. Manage., 2015, 163, 163-173.

44 H. Freundlich, Z. Phys. Chem., 1907, 57, 385-470. 45 I. Langmuir, J. Am. Chem. Soc., 1918, 40, 1361-1403. 46 M. M. Dubinin, Chem. Rev., 1960, 60, 235-241.

47 J. P. Hobson, J. Phys. Chem., 1969, 73, 2720-2727.
48 S. Ahmad, N. Khalid and M. Daud, Sep. Sci. Technol., 2002, 37, 343-362.

49 B. Czech, RSC Adv., 2016, 6, 110383-110392.

50 Q. Zhu, G. D. Moggridge and C. D'Agostino, Chem. Eng. J., 2016, 306, 1223-1233.

51 A. Hovsepyan and J.-C. J. Bonzongo, J. Hazard. Mater., 2009, 164, 73-80.

52 G. Boyd, A. Adamson and L. Myers Jr, J. Am. Chem. Soc., 1947, 69, 2836-2848.

53 J. Ma, F. Yu, L. Zhou, L. Jin, M. Yang, J. Luan, Y. Tang, H. Fan, Z. Yuan and J. Chen, ACS Appl. Mater. Interfaces, 2012, 4, 5749-5760.

54 K. V. Kumar, V. Ramamurthi and S. Sivanesan, J. Colloid Interface Sci., 2005, 284, 14-21.

55 M. Wawrzkiewicz, P. Bartczak and T. Jesionowski, Int. J. Biol. Macromol., 2017, 99, 754-764.

56 V. S. Munagapati and D. S. Kim, Ecotoxicol. Environ. Saf., 2017, 141, 226-234.

57 F. Yu, J. Ma, J. Wang, M. Zhang and J. Zheng, Chemosphere, 2016, 146, 162-172.

58 M. A. M. Salleh, D. K. Mahmoud, A. W. A. K. Wan and A. Idris, Desalination, 2011, 280, 1-13.

59 M. Mohd Amin, S. Heijman and L. Rietveld, Environ. Technol. Rev., 2014, 3, 61-70. 